\title{
Para um aprofundamento historiográfico: discutindo o separatismo paulista de $1887^{1}$
}

Cássia Chrispiniano Adduci Pontifícia Universidade Católica de São Paulo

RESUMO

Tendo como base pesquisa empirica realizada sobre o separatismo paulista de 1887, este artigopretende colocar em discussão característicasqueforam atribuídas ao movimento: sua estrita ligação ao republicamismoe seu caráter escravocrata. Otextotece também algumas observaçóes sobre os limites cromológicos do separatismopaulista de finais do séculopassado.

Palavras-chave: São Paulo; Separatismo; Republicanismo.
ABSTRACT

Based onamempiricresearchabout the 1887 "paulista"separatism, this article intendstodiscuss the characteristics that were assigned to the movement: its strict relation with therepublicanismand itsproslavery character. The text also composes some remarks about the chronological limits of the "paulista" separatism at the end of the 19th century.

Keywords: São Paulo; Separatism; Republicanism.

Diversos pesquisadores dedicaram-se ao estudo do período de passagem do Império para a República no Brasil e muitos deles analisaram, especificamente, o ideal republicano. Todavia, até o momento, nenbum trabalbo tinba se voltado para o exame da documentaçáo produzida pelos adeptos do separatismo em São Paulo durante o ano de 1887. Foi este o objetivo do presente artigo que busca identificar as características do ideárioseparatista paulista: seus aspectos doutrinários, suas propostas, seus ideólogos e propagandistas. Se é que realmente estas idéias transformaram-se, como afirma Emília Viotti da Costa, em mitos poderosos durante a Primeira República ${ }^{2}$, seráo importante tentar com- 
preendê-las no momento em que, pela primeira vez, elas apareceram de modo mais explícito na bistória de São Paulo.

O embate político em torno de uma maior autonomia regional náofoi característica exclusiva do período final do Império. Muito pelo contrário, durante a vigência da monarquia no Brasil, em muitas ocasióes houve movimentos que reivindicaram, se nem sempre uma república federativa, ao menos uma ampliação do grau de autonomia das províncias em face do poder central.

Nas décadas finais do século $X X$, as tensóes entre centralização e federalismo acirraram-se como conseqüência das dificuldades que províncias em expansão econômica encontravam para se imporem no momento das decisóes políticas. Assim, a idéia federalista ganbou um novo impulso. Mas, como aponta Sérgio Buarque de Holanda, esta idéia poderia apresentar diferentesmatizes, nem sempre significando um choque direto com a monarquia. Ofederalismo poderia surgir "de um comportamento arcaico e nitidamente contra-revolucionário, o da devoção às 'pátrias pequenas', em prejuizo, se preciso, da pátria maior”; ou solucionar um dos problemas da monarquia representado pelos presidentes de província, "que funcionavam quase unicamente como agentes eleitorais do governo central ou do partido no poder"; havia também os que defendiam uma administração mais moderna para o país, exigida pelos “tempos novos” e pelas "imposiçóes doprogresso"3.

Pontos de Partida

Ocontato inicial com as idéias separatistas paulistasfoi estabelecido a partir do livro O movimento de 1887, de Tácito de Almeida. Tratando o assunto de forma apaixonada, oautor destaca a manifestação de idéias separatistas em São Paulo, sobretudo no ano de 1887, quando "já não é mais em segredo, em voz baixa, que os paulistas falam em separação"”.

Tácito de Almeida aponta os principais “intérpretes” destas idéias: Francisco Eugênio Pacheco e Silva, Joaquim Fernando de Barros, Alberto Sales, Martim Francisco Ribeiro de Andrada e Emiliano Pernetta'. Mas alerta que náo se tratava de "vozes isoladas. Eram portadores do pensamento geral, das aspirações da 
maioria consciente de São Paulo"'. Além dasfiguras de destaque, Tácito de Almeida retoma as discussóes, durante o congresso do Partido Republicano Paulista, em torno da moção separatista que foi apresentada. Seu adiamento teria significado "um golpe amortecedor e infeliz".

Não matou o separatismo, porque os separatistas, que constituiam a maioria pensante do Partido Republicano e dos outros partidos monarchicos, continuaram a agir e a firmar suas convicçóes, publicando os seus livros e folbetos. Mas, de certa fórma, para a massa irreflectida e ignorante, oadiamentofoi considerado uma condemnação da idéa. Antes não houvesse sido formulada a moçãoao Congresso. Então, a campanha poderia prosseguir porfora, na sua esphera legitima, acima de todos os partidos.

Oautor indica ainda os que, a seu ver, teriam sido os principais inimigos do separatismo e os responsáveis pelo enfraquecimento do movimento de 1887: a propaganda federalista, a ilusão republicana, a ilusãofinanceira e a ilusão de begemonia ${ }^{7}$. Essas considerações levaram à localização de outras referências às idéiasseparatistas.

Emília Viotti da Costa define o movimento republicano como fruto do encontro de três forças: parte do exército, influenciado pelo pensamento positivista e imbuída da idéia de "salvar a pátria"; os fazendeiros do oeste paulista que desejavam realizar suas “aspirações de mando"; e representantes das classes médias urbanas, grupo antiescravista e que pretendia maior participação política. Auxiliavam este movimento o desprestígio da monarquia e o enfraquecimento das oligarquias tradicionais ${ }^{8}$.

Para a autora, as idéias separatistas paulistas teriam surgido da contradição entre o poder econômico e o poder político dos fazendeiros do oeste paulista que tiveram um grande desenvolvimento econômico, mas náo assistiram ao igual crescimento de sua representatividade política junto ao governo?. Esta posição contraditória teria dado margem aofortalecimento da idéia de federação - que, de qualquer forma, nunca teria chegado a desaparecer do programa do Partido Liberal -e, entre os mais extremados, ao começo de uma campanba pela separação. 
Segundo Emília Viotti da Costa, os defensores do ideário separatista formaram, neste período, um grupo bem menor do que o que apareceu em 1932. No entanto, sua própria existência teria revelado o nível de gravidade das tensóes da época. A ameaça separatista preocupava: em 1885, Joaquim Nabuco, em um discurso na Câmara dos Deputados, propunba que a monarquia realizasse a federação para que fosse possível ampliar a eficácia da administração e impedir o crescimento das idéias separatistas "o grande perigo", "o maior desastre"10. Independentemente do grau de adesão das idéias separatistas, a autora identifica, já nos primeiros artigos publicados nos jornais Gazeta de Notícias do Rio de Janeiro e A Província de São Paulo em 1877, o início das "manifestaçôes da 'mística paulista' e do espírito separatista que se converteram em mitos poderosos durante a Primeira República e que ainda boje são cultivados por indivíduos que vivem presosaopassado"11.

Décio Saes compreende o período no qual se insere o movimento republicano como um momento dentro do processo de for104 mação do Estadoburguêsno Brasil, vendona luta republicana diferentes classes sociais em defesa de objetivos políticos distintos, mas que não apresentavam, dentro do movimento, posiçóes claramente demarcadas. As classes dominantes, independente de serem escravistas ou não, iriam se colocar contra a transformação burguesa do Estado, que o autor liga a ofim do escravismo è c̀ criação do igualitarismojurídico burguês. Ogrupo que teria sido oportador desta ideologia burguesa foi a nascente classe média, entendida enquantotraballhadoresnão-manuaise não-proprietários ${ }^{12}$, cabendoa ela a responsabilidade pela transformação do Estado escravista moderno em Estado burguês. As classes dominantes de São Paulo somente teriam intervido no processo de reordenamento do Estado, quando sua transformação estava irremediavelmente dada, como objetivode adaptá-loaosseus interesses ${ }^{13}$.

Segundo Saes, o desejo de descentralização expresso pelas classes dominantes paulistas -que se sentiam sub-representadas no governo central -significava "a conquista do controle sobre os instrumentos de política econômica". A proposta federalista, no entanto, colocava os cafeicultores paulistas contra a monar- 
quia, já que seriam inviáveis "dinastiasmonárquicas provinciais". Deste modo, a autonomia reivindicada somente seria possível sob a forma republicana. As opçóes ficariam reduzidas ao separatismo republicano ou à república federal.

O separatismo republicano, para Saes, nãoteria sido viável até ofim dos anos 80 em virtude da existência de um "mercado nacional de escravos" e da conseqüente "solidariedade supra-regional entre os interesses escravistas"14. A opção pelo separatismo viabilizou-se "a partir do momento em que a ação conjugada do tráfico interprovincial e do movimento antiescravista logrou 'desescravizar' certasprovíncias (Ceará e Amazonas, 1884) e enfiraqueceu a resistência escravista noutras províncias". Aí então a separação passou a representar "o melhor modo de defender a escravidão contra o movimento abolicionista nacional"15, opondo-se tanto ao grupo que defendia a federação, quanto à facção das classes dominantes paulistas que, diante do crescimento do movimento antiescravista, aproximou-se do Estado monárquico. Saes, da mesma forma que Emília Viotti da Costa, aponta a tendência separatista como minoritária entre as classes dominantes paulistas, inclusive por sofrer oposição do capital imperialista inglês.

No volume da obra História Geral da Civilização Brasileira referente à passagem do Império para a República, Sérgio Buarque de Holanda afirma que a situação de instabilidade do Impériofoi fruto da excessiva centralização do sistema e da dificuldade encontrada pelas províncias economicamente mais dinâmicas e em expansão para prevalecerem, no âmbito político, sobre as áreas tradicionais. Nestes contextos mais dinâmicos, a idéia liberal, que poderia estar ou náo ligada ao republicanismo, teria adquirido novaforça ${ }^{16}$.

Ainda segundo Sérgio Buarque de Holanda, as idéias separatistas que surgiram no final do Império, destacadamente no Rio Grande do Sul e em São Paulo, teriam se apresentado como uma alternativa para o caso de náo ser adotada a forma republicana e federativa de governo. Ao contrário de Emília Viotti da Costa e Décio Saes, aquele autor considera o separatismo paulista um movimento de grande repercussão, “como seria de prever”, tanto dentro como fora da província. "Oadmirável é que, atéfora de 
São Paulo, e entre brasileiros de outras províncias, o mesmo movimento despertasse simpatias que dificilmente se poderão conceber no país depois do estabelecer-se nele a república federativa". Oautor menciona as reaçóes simpáticas ao movimento vindas de outras províncias e também aponta, por outro lado, a resistência que se desenvolveu no norte de São Paulo -"espécie de separatismo contra o separatismo"17.

Outros estudiosos, em trabalbos mais específicos, também fizeram referências às idéias separatistaspaulistas. Wilson Martins, aoapontar a influência exercida pelas idéias positivistase evolucionistas no Brasil, argumenta que elas deveriam ter estado mais presentes no programa dos republicanos, mas que, ao contrário, em face da "realidade cotidiana da vida pública e dos partidos"os caminhos foram outros, chegando ao ridículo e ao inesperado. $O$ exemplo dado pelo autor é o separatismo paulista:

(...) assim, por exemplo, Sáo Paulo conbecia, a essa altura, um movimento separatista (que náo era oprimeiro, nem seria oúltimo desuabistória), insufladoporpolíticos que, detoda evidência, tinham as doutrinas e as idéias na mais escassa estima. Isso levou um fabricante mal sucedido a chamar de 'bonecas separatistas' os monstrengos que fazia, com cabeças de porcelana vindas da Alemanha, eque nem assim conseguiam encontrarcomprador (... $)^{18}$.

Wilson Martins, como Décio Saes, também destaca o caráter escravocrata do separatismo ${ }^{19}$. Para o autor, o ideal republicano somente teria servido como pretexto às tendências separatistas ${ }^{20}$. Além disto, Martins, ao tratar do romance naturalista $O$ Cromo, de Horácio de Carvalbo, destaca o aparecimento, na obra, do movimento separatista paulista. No capítulo LX, Carvalbo teria aberto um parênteses para afirmar que durante o ano de 1888 SãoPauloteria sidomarcado "pordois grandes problemas: oseparatismo e a abolição" (na verdade, o texto de Carvalbo se passa em 1888. No início deste ano, o autor afirmava que a província de São Paulo “achava-se em lucta” com estes dois problemas). Depois de citar rapidamente os principais separatistase suasobras, o autor observou que o separatismo teria ficado para segundo plano a partir do crescimento do abolicionismo. 
Alguns autores apontam o separatismo paulista como uma radicalização do federalismo. Suely Robles Reis de Queiroz destaca que, apesar "das numerosas adesóes e de poucas manifestaçóes reticentes”, a idéia radical não teria prevalecido no congresso do Partido Republicano Paulista de 1887. Segundo a autora, "a solução republicana federativa" teria sido a mais indicada já que atendia aos interesses das "zonas agrárias mais adiantadas sem por em risco a unidade nacional"' .José Ênio Casalecchi aponta a estreita ligação entre o desenvolvimento da província de São Paulo e as idéias separatistas; estas idéias indicariam também "a força dofederalismo no ideário republicano"22.

O separatismo dentro do Partido Republicano Paulista foi igualmente destacado por outros pesquisadores que se preocuparam, como Casalecchi, mais detidamente com a análise do partido. Para George Boehrer, o PRP teria assumido, em relação ao separatismo, a mesma posição ambivalente que adotou diante da abolição: a tentativa era evitar maiores comprometimentos ${ }^{23}$. Na visáo de Célio Debes, o separatismo dentro do PRP teria surgido como um meio que viabilizasse seu principal fim: a federação, estando a ela "estreitamente ligado". Apesar de "simpático" ao ideário separatista, opartido teria optado por adiar a tomada de uma posição oficial'.

Uma pesquisa empírica minuciosa acabou demonstrando, no entanto, que algumas das consideraçóes feitas até o momento sobre o separatismo paulista de 1887 precisam ser reavaliadas. Aprimeira delas refere-se à estrita ligação das idéias separatistas como republicanismo. Opróprio movimento identifica um separatismo monárquico e um republicano. Outro ponto a aprofundaré sobre seu caráter escravocrata, além de algumas observações sobre seus limites cronológicos. Assim, a seguir, este artigo pretende expor alguns novos elementos para uma melhor compreensáo do movimento separatista paulista de finais do século passado.

CONSIDERAÇÕES PARA UM APROFUNDAMENTO HISTORIOGRÁFICO

Entre as fontes utilizadas, Está principalmente, a imprensa da cidade de Sáo Paulo durante o ano de 1887, com destaque para osjornais Diário Popular e A Província de São Paulo. Dois 
livros que veicularam o separatismo, publicados pelos dois principais ideólogos do movimento -Martim Francisco e Alberto Sales -, também foram analisados ${ }^{25}$; assim como outras obras publicadas no período e que faziam referências ao ideário. Houve a preocupação ainda de apreender como essas idéias repercutiram em outras cidades da Província e fora dela. Assim, foram consultados os periódicos das duas principais cidades da Província depois de São Paulo, Campinas (Gazeta de Campinas, Diário de Campinas e Correio de Campinas) e Santos (Diário de Santos); e do Rio de Janeiro (Jornal do Commercio, Revista Illustrada, O Paiz, Gazeta da Tarde e Novidades).

É preciso salientar que ofoco centralfoi a imprensa paulistana. No entanto, como se mostrou necessário buscar entender a forma como essas idéias apareceram e foram questionadas ou apoiadas em outros contextos, foi necessário empreender um levantamento de tais repercussóes. Também com o objetivo de compreender melbor os ideólogos e o período em questão, foram utilizados os Anais da Assembléia Legislativa da Província de 108 São Paulo dos anos de 1878, 1879 e 1887 e algumas outras obras de Martim Francisco e Alberto Sales, assim como textos de vários autores de finais do século XIX que também se preocupavam em apresentar alternativas à crise que enfrentavam.

Em contraposição a projetos que, de formas diferentes, propuseram soluçóes para a nação brasileira pensada em sua integralidade ${ }^{26}$ surgiu a proposta do separatismo, que enfrentou o conturbado contexto brasileiro de final do séculoXX, "extirpando" os "obstáculos".

Como já foi mencionado, o primeiro desafio a ser vencido, foi o de tentar estabelecer limites cronológicos para o movimento. No debate pela imprensa, dois jornais, A Província de São Paulo e, principalmente, o Diário Popular, abriram espaço significativopara oassunto.

Tácito de Almeida datou o início do movimento em 11 de fevereiro de 1887 com a publicação do primeiro artigo em defesa do separatismo paulista assinado por Francisco Eugênio Pacheco e Silva, sob o pseudônimo de Feps, no Diário Popular. Na verdade, Martim Francisco Ribeiro de Andrada, usando opseudônimo 
de Nemo, já vinha escrevendo sobre a superioridade paulista e sua condiçấo de pagadora do Império na seção "Commentarios”, do mesmo periódico. Em janeiro de 1887, Nemo, com o mesmo tom irônico que marcou toda a sua produção, havia publicado dois artigos (em 22/01 e 28/01) em que reclamava das diferenças de receitas entre as províncias e de cortes de verbas para São Paulo.

Além disto, o mesmojornal noticiava, em 03 de fevereiro, que Nemo estava escrevendo um livro intitulado Pátria Paulista ${ }^{27}$. “Amigo Nemo", artigo publicado n'A Província, em 11 de fevereiro, por outro dos principais participantes dos debates em torno das idéias separatistas, Joaquim Fernando de Barros, parece reforçar ainda maiso papel de Nemo como o iniciador do movimento. Barros afirmava comungar de suas idéias separatistas.

Mais um texto explicita a antecedência do movimento. Foi um editorial publicado em A Província de São Paulo, em 08 de fevereiro, que reclamava sobre o corte de verbas que a província tinha sofrido para manutenção da força pública ${ }^{28}$. Diante da explicação de que a Província teria sido excluída por possuir condiçóesfinanceiras para se sustentar, ojornal afirmava:

Quando a idéa de separação ganba terreno e nos partidos monarchicosmesmo apparecem 'separatistas', esse acto do governo vem fortalecer os que procuram uma nova agremiação politica.

Não vale, pois, a pena ser rica para soffrer todos os encargos determinados pela uniáo e pelo proteccionismo do regime centralisador e tudo isso em beneficio das outras provincias e em desproveito proprio.

A provincia de S. Paulo é incontestavelmente a que supporta boje maiores sacrificios affim de favorecer as outras ${ }^{29}$.

Mesmo antes de 1887, é possível localizar, em alguns textos de Martim Francisco (reproduzidos em seu livrocitadoacima), idéias associadasaoideário separatistaqueoautorajudaria a elaborar anos depois. Em um discurso pronunciado na assembléia provincial de Sáo Paulo em março de 1879, a idéia da superioridade de condiçóes e da viabilidade de autonomia já estava presente:

Não quero cansar a attenção da assembléa com algarismo e comparaçóes; mas posso assegurar que, em consequencia de estudos, e bazeado em dados estatisticos, verifiquei não existir na America do sul região alguma que, tendo a mesma area 
agricultada que a provincia de S. Paulo, produza eguaes rendimentos.

Dá pena, senbores, ver tanta riqueza tão mal barateada; uma provincia que por si só poderia constituir um estado, e que, em menos de 10 annos de paz e de trabalbo, seria a primeira potencia da America do Sul, em virtude do desgoverno, póde ter por borisonte a bancarrota e o descredito ${ }^{30}$.

Estas idéias reapareceram em uma circular dirigida, por Martim Francisco, ao eleitorado do $5^{\circ}$ distrito da província em 18 de agosto de 1881:

Quando, iniciando uma carreira politica que tem sidofelizporque buscou arrimo na recusa de todas as posiçóes que não trouxessem o cunbo do voto popular, pedi ao eleitorado uma cadeira na representação provincial, declarei que mais prezava o titulo de paulista do que o de brazileiro. Essa affirmativa, pronunciada sob o influxo de entbusiasmo que era tão juvenil quanto sincero, renovo-a boje, boje que o estudo mais prolongado dos negocios e das necessidades publicas, da marcha dos acontecimentos e da nossa bistoria politica, me fornece outros e valiosos subsidios para o conbecimento dos bomens e para a pratica das cousas. o progresso espantoso da provincia; a exiguidade numerica de sua representação; a grandeza de sua renda e muitos outros factos de que o povo tem noçáo correcta, me aferram á crença de que não devo desertar de idéas expendidas na primeira circular que dirigi ao eleitoradopaulista ${ }^{31}$

Em discurso promunciado na Câmara dos Deputadosem agosto de 1884, Martim Francisco tratava de sua despedida da vida pública, uma despedida ressentida em conseqüência da ainda injusta posição ocupada pela província que representava, da imutilidade de seu trabalbo, da falta de consideração por parte do governo central e, razáo principal da "infelicidade” da província, do pouco valor de sua deputação. O autor encerrava apontando os principais pontos de apoio do discurso separatista:

Negam-nos tudo! Quando queremos progredir, ostentam-se contra nós os anneis da engrenagem centralisadora; occupam os nossos empregos com gente estranba á nossa vida, aos nossos interesses e aos nossos meios de acção; recusam-nos até policia, afugentando para S. Paulo os gatunos e a escoria da população perseguida aqui pelos agentes da autoridade, e dando para o policiamento de umazona extensissima a minguada quantia de 3:000\$, 
pela verba secreta; abafam ou recusam noparlamentoosprojectos que são portadores de qualquer utilidade para nós. ${ }^{32}$.

Como os descontentamentos de parte das classes dominantes paulistas diante da posição ocupada pela província frente ao poder central náo era recente, acumulando-se desde que estes mesmos grupos passaram a sentir uma contradição entre seu poder econômico e seu poder político, é possível que esta realidade tenha aberto espaço para o aparecimento de diversas reclamaçóes que, ligadas aofederalismo, aos poucos, foram assumindo os contornos separatistas expressos em $1887^{33}$. Separatismo que teria sistematizado exteriorizado, de forma mais direta, manifestaçóes anteriores de uma "mística paulista".

A referência à adesão de monarquistas, expressa em citação anterior, aponta para a discussão de outra característica até então atribuída ao movimento: seu caráter estritamente republicano.

É controversa a data de saída de Martim Francisco do Partido Liberal. Em artigo de $1^{\circ}$ de abril de 1887, Nemo, após tecer críticas à atuação deste partido frente à questão da emancipação dos escravos, justificava sua permanência em seus quadros:

Prendem-me a esse partido innumeros laços; serei votante em suasfileiras até odia em que a propaganda separatista corporificarse em nucleo deliberante. Quizera vêl-o -e porque desesperar quando a propria côrte lhe dá liçóes? -na altura da independencia, do progresso e das tendencias autonomicas da provincia ${ }^{34}$.

Se istofoi afirmado em 1887, em maio de 1888, no discurso Abolicionismo e Separatismo, proferido em Santos durante cerimônia de entrega de presentes a abolicionistas, Martim Francisco afirmava ter se retirado do Partido Liberal em 1885. Além disso, o autor declarava-se "incompativel" com o Partido Conservadore “desconfiado"dos republicanos.

Quatro biógrafos consultados, no entanto, localizam a saída de Martim Francisco em período anterior. Leopoldo de Freitas, em Perfil biographico e politico de Martim Francisco, afirma:

Tornando aos trabalhos da Camara em 1884 proferiu notavel discurso para impugnar o augmento da representaçáo do Paráe de outras provincias nortistas, em nome dos grandes interesses de S. Paulo, então contrariados e menosprezados pela situação 
politica. Revestido de coragem e com sobranceria declarou-se definitivamente desligado do partido liberal.Justificou o separatismo e para desfraldar esta bandeira de combate-affirmou recusar nova eleição e deste modo trabalhar mais livre pela democracia paulista's5.

Além de retomar a discussão sobre o início da circulação de idéias separatistas na Província, este trecho dá elementos para o começo da discussáo sobre o caráter do movimento. Affonso de E. Taunay, em texto dedicado a Martim Francisco publicado na Revista do Instituto Histórico e Geográfico de Sáo Paulo, aponta a decepçáo do autor separatista com a política imperial em virtude "de grave injustiça" em relação a seu pai,justificando então, a partir da morte deste em $1^{\circ}$ de março de 1886, sua adesão às "fileiras republicanas". No Dicionário de Autores Paulistas, Luís Correia de Mello repete as mesmas informaçóes. Antônio Barreto do Amaral, no Dicionário de História de São Paulo, não especificou a filiaçãopartidária de Martim Francisco, referindo-se somente a seu retorno a São Paulo, com “inclinaçóes republicanas”, após ocupar a presidência da província do Espírito Santo.

Opróprio autor, no entanto, parece não se preocupar com a classificação do movimento: em artigo de 24 de março, considerava a propaganda separatista "politica e náopartidaria, impessoal'36. Em 16 de junbo, Nemo assinou texto em que explicitava uma posição crítica em relação aos republicanos:

\section{(...)}

Já tive occasião de consignar em portuguez que nem pela máfé conseguirá ser adulterado: não creio na republica em Sergipe, na federação em Tabatinga. Em paiz que se estende de norte a sul, com povos differentes e cada vez mais diversificados pelo clima, com producção, importação e costumes que se distanciam quotidianamente, a união pela monarchia é difficil, pela republica é impossivel.

(...)

Uma vez por todas: para a Patria Paulista prefiro a organisaçáo republicana com a fórma conservadora que já expliquei em jornal e em livro; para o Brazil, boje, só acho acceitavel o governo monarchico. Posso trabalhar ao lado dos que entendem que a separação é caminho para a federação e que o portuguez americano diverge do hespanbol americano. Odia de amanhan é mui- 
to amplo, e a federação divide-se em commercial, militar e politica(...)

Onde não devo assentar praça é na fileira dos que apenas se dirigem a uma classe contando que esta realisará, por si só, uma evolução eminentemente politica. Pensar que o estylo aprimorado e as conferencias pouco concorridas persuadiráo um povo cujos oito nonos desconbecem o alphabeto-é ser entbusiasta da vadiagem disfarçada.

(...)

Temo que a Patria Paulista dirigida por gente dessa força, bata no escolbo da inutilidade.

Tenbo menos receio da monarchia do que do idealismo ${ }^{37}$.

Três dos quatro principais propagandistas do separatismo Alberto Sales, Francisco Eugênio Pacheco e Silva eJoaquim Fernando de Barros-estavam ligados ao republicanismo; além disso, a publicação dos textos do movimento concentrara-se nos veículos republicanos A Província de São Paulo ${ }^{38}$ e Diário Popular $^{39}$. Não foi localizado nenbum número do Liberal Paulista, “orgam do partido liberal de São Paulo", e o conservador Correio Paulistano não abriu muito espaço ao assunto. Dentre as poucas referências ao ideário que fez, está um texto assinado por Iskander, no qual apareceram críticas ao separatismo, apontado como uma utopia, e a defesa de uma monarquia federativa ${ }^{41}$. Assim, apesar da predominância de veículos e ideólogos republicanos na divulgação das idéias separatistas, o posicionamento de Martim Francisco não permite caracterizar o movimento como estritamente republicano.

Na verdade, uma rivalidade entre um separatismo monárquico e um republicano veio à tona em artigo de 15 de junbo. Assinado por Um separatista (autor não identificado), o texto lamentava o surgimento, no seio do movimento separatista, de "sentimentos e ambições oppostas". O autor do texto, que bavia sido publicado em A Vida Semanária e estava sendo reproduzido em A Província de São Paulo, teria deixado

(...) transparecer claramente, lamentavelmente que existe um separatismo monarchico, com intuitos reservados, que se insurge contra o separatismo leal e sincero, tal como querem os republicanos e como elles prudentemente revelaram na ultima sessão do seu Congresso. 


\section{(...)}

Os republicanos, segundo declararam accentuadamente no Congresso, não querem encerrar oprincipio separatista no circulo apertado das aspiraçóes partidarias. Querem n'o com as vastas proporçóes de uma aspiração paulista. Mas, se os monarchicos collocam-se em um ponto de vista diverso, se elles querem o exclusivismo partidario; se, por outra, ha alguem que pretenda fazer o monopolio da idéa para introduzil-a no seio dos outros partidos como um scisma politico, como o elemento de anarchia e dissoluçãopartidaria, então é indispensavel que os republicanossaibam guardaraverdadeiraattitude.

Uma de duas: ou trata-se de formar uma Patria Paulista para a democracia; ou trata-se de fundal-apara a monarchia.

No segundo caso é evidente que não se deve nem se póde contar com a collaboração dos republicanos. No primeiro caso, porém, porque razáo os monarchicos, em vez de confraternisarem lealmente, francamente com os republicanos; ao contrario, tentam affastar o seu concurso, estigmatisando com a vehemencia da injuria a sua conducta?

Dando continuidade à polêmica, novo artigo foi publicado em 17 de junbo, assinado por um Separatista republicano (autor náo identificado). O autor náo aprovava o que teria escrito um separatista "de filiação monarchica": Martim Francisco. Este teriaafirmado:

Para convencerem opovo da necessidade da republica federativa, perderamjá os republicanos 17 annos desperdiçadamente empregados em conferencias longas, em elogios pessoaes e em publicações de livros que se dirigem a uma só classe, composta em regra de individuos que sabem mais do que o autor dofolbeto ${ }^{43}$.

O Separatista republicano saiu em defesa dos republicanos e atacou Martim Francisco:

É livre a cada um affirmar ardentemente a suafé separatista, conservando entretanto, a mesma crença politica que antes professava. Exemplo: o sr. Martim Francisco Filho, separatista apaixonado e fogoso, protesta lealmente a sua fidelidade á bandeira do liberalismo monarchico, pelo menos 'emquanto nãofor fundada a estremecida Patria Paulista'.

Isto quer dizer que o sacrificio náo começa no ponto de partida. Náo haverá o ostracismo, o invencivel terror da politica cesa- 
riana. Permanecerá sempre aberto e franco o acesso às posiçóes ambicionadas.

Aquelle que tiver a ventura de se apresentar um bom servidor aos olbos dos poderosos chefes, chegará seguro até as maiores alturas dapromoçãopartidaria. Bastará para isto esperarodia da situação; isto é o dia em que cessa o ostracismo e começa o governo.

Abi está o que é a verdadeira posição para o separatista de filiação monarchica. 'Não ha parola nem rbetorica', mastambem não ha perigos.

Não é justo portanto o confronto.

Mas, para que servem as injurias e as provocaçóes? A idéa separatista ha de ir procurar bons adeptos lá onde formaissincero, mais leal e mais ardente o patriotismo. Mas onde se encontram os bons patriotas, senão entre estes heroes que se batem pela republica sem contar o tempo das luctas nem tomar o peso dos sacrificios? ${ }^{\text {fit }}$

Por esse texto, Martim Francisco está totalmente dissociado do republicanismo, oque impede caracterizar oseparatismo como um movimento vinculado exchusivamente às idéias republicanas.

Nos doisjornais-Diário Popular e A Província de São Paulo, os artigosseparatistas apareceram concentrados entre osmeses de fevereiro e agosto, nagrande maioria dasvezes, na primeira página dosperiódicos Apartir da não aprovaçãoda moção separatistaapresentada no congresso do Partido Republicano Paulista realizado em maio, bouve ainda algumas discussóes na imprensa, mas, aospoucos, o assuntofoisendo substituídopela questão abolicionista. Martim Francisco foi o único que continuou escrevendo sobre o separatismo até início de 1888. Então n'A Província de São Paulo, o autor assinava columa intitulada “Interesses Paulistas". Sua despedida, correspondendo aofinal da minha pesquisa, foi no artigo "Apontamentose... despedida”, de 25 de março.

Martim Francisco reiterou a necessidade da separação: 'scientificamente comprehendida e valentemente executada', somente ela possibilitaria 'um futuro mais limpo'. Oautor enxergava a proximidade da autonomia em um momento em que a campanbajá havia praticamente terminado. Edespedia-se então:

Durante dois annos, os mais activos, os mais difficeis e os mais estudiosos de minha existencia, provoquei e agitei a propaganda separatista nesta provincia, sem descanso de um dia, sem intersticio de uma bora. 
A idéa adquiriu direito de cidade no espirito publico. É discutida, foi melhorada, tem sido geralmente acceita.

Ellajá não precisa de mim.

Sargento da vanguarda até boje, recolbo-me satisfeito á posição modesta que me compete e declaro-me prompto ao alerta que for bradado pelo chefe que os acontecimentos designarem.

Guardando a penna que ha dous annos emprego na defeza dos interesses paulistas, ausento-me da propaganda, pronunciando as mesmas palavras que deram fecho á minha vida de politicopartidaria na camara dos deputados em 1884: 'espero acontecimentos mais accentuados que me proporcionem occasião de servir a liberdade e a patria'.

Eminha patria é exclusivamente a zona paulista ${ }^{45}$.

Ainda em 1888, no discurso Abolicionismo e Separatismojá citado, Martim Francisco tentou envolver os abolicionistas com a causa separatista: "Mãos á obra, triumphadores! Não recuseis deante dum novo desvario patriotico: -após a abolição immediata e incondicional, clamae pela separação immediata, separação incondicional (sim! sim!)"'6.

Mais um ponto acerca do movimento separatista paulista de 1161887 deve ser esclarecido: o caráter escravocrata que lbe é atribuído por alguns autores. Na verdade, este é um ponto exemplar para ilustrar as contradições vividas pelos que se esforçavam em procurar saídas para o país. Contradiçóes que apareceram, por várias vezes, nos discursos estudados.

Na análise que faz do republicanismo paulista, Décio Saes caracteriza-o, e dentro dele oque denomina "separatismo republicano", como um movimento escravista, nascido para fazer frente ao crescimento que assistia o abolicionismo no Brasil. Viabilizado em conseqüência do fim do "mercado nacional de escravos" e da quebra da "solidariedade supra-regional entre os interesses escravistas", o "separatismo republicano" teria se tornado uma opção "para as forças sociais escravistas que defendiam a separação da província de Sáo Paulo, essa medida aparecia como o mellbor modo de defender a escravidáo contra o movimento abolicionista nacional. Essa era a natureza - escravista-doseparatismorepublicano de políticos paulistas como Martim Francisco e Alberto Sales, nofinal da década de $80^{\prime \prime 4}$. 
Sobre o caráter escravista do movimento, o autor remete, em nota, aos traballbos de Robert Conrad eJamil Haddad. Conrad retoma um debate ocorrido entre Jeronymo Sodré e Martim Francisco na assembléia geral, em 1879. Sodré teria criticado a Lei Rio Branco e afirmado, segundo escreve Conrad, que "os liberaisbrasileiros eram obrigados a ir além do trabalbo dos conservadores, a declararà nação que todos os brasileiros eram cidadãos, que todos eram livres". Odeputado teria conchúdo seu "discurso bistórico com um apelo para a extinção total e rápida da escravatura".

Martim Franciscoteria respondido "apressadamente" a Sodré, defendendo a escravidão e insinuando "que os interesses do café prefeririam desmembrar o Império a ver o sistema de trabalbo destruído por uma legislatura dominada pelos deputados de outras regióes". Conrad cita então trecho do discurso pronunciado por Martim Francisco:

Nós, os representantes das províncias do sul do Império, disse este paulista, neto do líder da Independência, José Bonifácio de Andrada e Silva, apreciamos a integridade deste vasto paiz, mas não tanto que, para conserval-a, queiramos tolerar a liquidação geral dasfortunas e a destruição violenta da propriedade escrava, para que tanto têm concorrido as grandes remessas, que nos têm feito as províncias do norte, de escravos, que nos vendem por avultada somma ${ }^{48}$.

Sem dúvida que este discurso defendia interesses escravistas. O problema é que o Martim Francisco em questão era pai do Martim Francisco defensor do separatismo de 1887. Mesmo porque, em 1879, Martim Francisco (ofilbo) ocupava uma cadeira de deputado sim, mas na Assembléia Provincial de São Paulo. Onde, inclusive, em discurso pronunciado em 22 de março, identificava-se como abolicionista.

Odiscurso de Martim Franciscofoi promunciado durante debate que antecedia a votação do estabelecimento de um imposto sobre a entrada de escravos na província de Sáo Paulo. Como aponta Célia Maria M. de Azevedo, tratava-se da segunda votação do projeto antitráfico, discutido no ano anterior. As tensóes, em 1879, estavam mais agudas como conseqüência do aumento dos atentados dos escravos contra seus senbores, o que implicou a 
mudança de posição de alguns deputados, inclusive de Martim Francisco, que teriam explicitado "seu voto a favor como uma mudança a contragosto, porém inevitável, devido à insegurança propiciada pela revolta dos escravos" $"$.

Apesar de ter votado, em 1878, a favor dos interesses dos proprietários de escravos e, em 1879, ter mudado seu voto por terem se alterado as condiçóes da Província -o que teria levado, inchusive, muitosfazendeiros a defenderem a idéia -, Martim Francisco preocupou-se em afirmar que, não sendo "lavrador", votava seguindo "a opiniáo dos provectosna materia. Sáoellesos interessados; são elles os que pedem providencias á assembléa, cujo dever é garantir-lhes a propriedade e afortuna". Fez questão, todavia, de afirmar-se abolicionista: "Comov. ex. sabe, sou abolicionista. Quero, porém, fazer inventario das minhas aspiraçóes democráticas em favor da Provincia. Faço-o neste momento"

É interessante observar, no entanto, a fala de Martim Francisco antes desta afirmação. Além de fazer referência à existência de idéias separatistas no Norte, ofuturo separatista paulista temia, 118 como afirma Célia Maria M. de Azevedo, que se pudesseformar, no norte e nordeste, um Estado separado livre de escravos ${ }^{51}$. Mas não só não se atrevia a levar seu "abolicionismo" a uma proposta mais ousada, como criticava um pedido de abolição imediata (grifomeu):

É sabido que no norte a idéa separatista é popular e corrente hoje, como realidade imminente; e o norte do imperio náo cessa de enviar escravos para a nossa provincia. (...) A unica provincia do norte que ainda vacilla é a Babia, que ainda tem muitos escravos! Pois bem! Ultimamente um representante dessa provincia teve a 'infeliz idéa' de exigir do governo a decretação immediata da liberdade dos escravos ${ }^{2}$.

Écerto que alguns emancipacionistas viam a necessidade de se vincular of fim da escravidáo com outra forma de viabilizaro traballbo, a colonização. Oque parece ser ocasode Martim Francisco, a se julgar por trecho de discussáo anterior entre este e Martinbo PradoJr. durante o ano legislativo de 1878:

Martim FranciscoJr. -Se nos fosse possível, ao lado desse projeto que, em fundo, contém uma idéia magnifica, tomar providências relativas à colonização, de modo que ofazendeiro pudesse 
substituir o trabalbo escravo pelo trabalbo livre, en votaria pelo projeto.

Martinho PradoJr. -Enquanto houver escravos não é possivel a colonização.

Martim FranciscoJr. -Enquanto náobouver colonizaçáo bavemos de ter escravos.

Martinbo PradoJr. -Já existe, e náo se desenvolve por causa da instituição de escravos.

Martim FranciscoJr. -Não se acabam os escravos porque não se facilita a colonização $0^{53}$.

Em discurso promunciado na cerimônia de entrega de presentes a abolicionistas, em Santos, em 1888, Martim Francisco explicou-se diante da causa abolicionista. De início, reconbeceu ter feito quase nada pela causa emancipacionista, justificando-se por problemas de saúde e de "embaraços materiaes". Insistiu em dizer, todavia, que nunca havia sido "responsavelmente, dono de carne bumana". Estas afirmaçóes foram seguidas por uma crítica aos que, às vésperas da publicação da lei de abolição e sem terem feito algo efetivo pela causa emancipacionista, apresentaram-se como "responsaveis pelo triumpho".

Asjustificativas de Martim Francisco deixam dúvidas. Durante 1887, período em que o movimento abolicionista já bavia deixado para trásorisco de uma adesáo a suasfileiras, oautor escreveu com grandefreqüência nosjornais, masseu interesse era outro: oseparatismo. Martim Francisco avaliou um processo de emancipaçãogradual, sem, no entanto, dedicarmaior atenção aoproblema ${ }^{54}$.

Na verdade, em muitosmomentos, os discursos dos ideólogos separatistastentavam equilibrar uma vivência "tradicional"com uma série de "modernidades teóricas" que estes autores - mas náo só eles - esforçavam-se por colocar "em prática”. Os choques entre estes dois mundos apareceram de modo evidente nos textos da época. Uma efetiva realidade arcaica estava "tendo de ser" transformada em algo moderno. Osproblemas advindosdeste desafio surgiam a todo instante, com mais freqüência quando o que se debatia era a questão escrava. Um "discurso moderno" exigiria uma coerente "atitude moderna": este foi o grande desafio imposto a vários ideólogos do período. 
De certa forma, a postura de Martim Francisco repetiu-se nos discursos dos demais separatistas possibilitando esclarecer meIhor a questão escrava dentro do separatismo paulista. Entretanto, comojáfoi mencionado, a bistoriografia tem posiçóes divergentes a respeito da questáo. Décio Saes, por exemplo, caracterizou o movimento como uma reação ao avanço abolicionista.

Ocaráter escravista atribuído porJamil A. Haddad ao separatismo paulista liga-se à obra de Alberto Sales, A Pátria Paulista. O autor assim traduz o discurso de Sales: "Vamos decomporo Brasil, que depois o puzzle se recomporá. Cientificamente. Ideologia científica para uma desagregação certamente desejada e uma recomposição só aceita, desde que bouvesse acôrdo entre outras províncias e São Paulo, no tocante à escravidão e o resto" 55 .

Wilson Martins também confere ao movimento paulista um caráter escravocrata: "Não será temerário sugerir que provinha, direta ou indiretamente, dos meios escravocratas paulistas aforte campanba separatista que então se desenvolvia na província, comandada por bomens do porte de Martim Francisco, Rangel Pesta120 na e Ubaldino do Amaral'56. Oautor segue citando trechos de falas dossupostosseparatistas, mas em nenbuma delas bavia referências explícitas que permitissem a associação clara da defesa do escravismo com o movimento separatista. Sobre Martim Francisco, este artigo já expôs algumas de suas contradições em relação ao assunto. Oapoio de Rangel Pestana e Ubaldino do Amaral ao separatismo, sugeridopor Martinsfoi questionadopelosprópriosparticipantes do debate em torno destas idéias. Logo, independente destes dois políticos serem ou não defensores da ordem escravista, eles com certeza não se identificaram expressivamente com o movimento separatista.

É inegável o caráter escravocrata dosfazendeiros, bem como sua mudança de atitude às vésperas da aboliçấo: com medo de perder o controle sobre a máo-de-obra e pressionados pelas crescentes fugas que ameaçavam desestruturar o trabalbo nasfazendas, os cafeicultores do Oeste paulista já baviam dado início, em 1887, ao processo de emancipação, ainda que de modo gradual.

Levando em consideração este contexto, é possível argumentar que, ao contrário de representar os desejos de dar continuidade 
à escravidão, o separatismo paulista talvez representasse os anseios dos que, ainda que pretendendo maior autonomia, teriam aberto mão dela até aquele momento, justamente em função da permanência da instituiçáo escrava. Ou seja, aoter-se tornado inevitável ofim da escravatura, os motivos para a manutenção da unidade teriam desaparecido. Ofoco central de atenção dos fazendeiros teria se voltado, entáo, para a agora ainda mais necessária autonomia provincial (principalmente em função dos desejos de maiores investimentos em torno da imigração). Para a maioria deles, a melhor opção seria uma federação republicana, para um menor número, a solução estaria na separação. Neste sentido, o separatismo teria adquirido um caráter de radicalização apenas formal em relação aofederalismo, constituindo, na verdade, uma alternativa frente a este, conforme já havia apontado Sérgio Buarque de Holanda 57 .

De todo modo, os novos pontos discutidos neste texto, acerca do separatismo paulista de finais do séculoXX, permitem a continuidade do debate para um aprofundamentobistoriográfico do tema.

\section{NOTAS}

${ }^{1}$ Artigo produzido a partir da dissertação de mestrado A "pátria paulista": o separatismo como resposta à crise final do Império brasileiro. São Paulo, PUC, 1996 (financiamento CNPq).

${ }^{2}$ COSTA, Emília Viotti da. Da monarquia à república: momentos decisivos. São Paulo, Brasiliense, 1987, p. 346.

${ }^{3}$ HOLANDA, Sérgio Buarque de. “O manifesto de 1870”. In História Geral da Civilização Brasileira, t. II, vol. VII, São Paulo, Difel, 1972, p. 268.

${ }^{4}$ ALMEIDA, Tácito de. O movimento de 1887. São Paulo, s./e., 1934, p. 18.

${ }^{5}$ Na pesquisa empírica, nãoforam localizadas as participações de Emiliano Pernetta na elaboração do ideário separatista paulista. No entanto, Tácito de Almeida destacou a participação de Pernetta através dojornal A Vida Semanária do qual só foram encontrados exemplares a partir do número 10, quando ojornal estava sob a direçáo de Olavo Bilac e não mais de Pernetta. Os primeiros números do jornal constam do arquivo da Faculdade de Direito da Universidade de São Paulo, estando, no entanto, extraviados.

${ }^{6}$ ALMEIDA, Tácito de. op. cit., p. 32.

${ }^{7}$ Idem. pp. 42-58.

${ }^{8}$ COSTA, Emília Viotti. op. cit., p. 361.

${ }^{9}$ Idem. p. 344.

${ }^{10}$ Idem.pp. 342-343.

${ }^{11}$ Idem. p. 346. 
${ }^{12}$ SAES, Décio. Aformação do Estado burguês no Brasil (1888-1891). $2^{a}$ ed., Rio de Janeiro, Paze Terra, 1990, p. 276.

${ }^{13}$ Idem. pp. 264-266.

${ }^{14}$ Idem. p. 256-257.

${ }^{15}$ Idem. p. 259.

${ }^{16}$ HOLANDA, Sérgio Buarque de. op. cit., p. 258.

${ }^{17}$ Idem. pp. $277-278$.

${ }^{18}$ MARTINS, Wilson. História da inteligência brasileira. São Paulo, Cultrix, 19778,p. 114.

${ }^{19}$ Esta mesma característica foi apontada ainda por HADDAD, Jamil A. Revolução cubana e revolução brasileira. Rio de Janeiro, Civilização Brasileira, 1961.

${ }^{20}$ MARTINS, Wilson. op. cit., p. 247.

${ }^{21}$ QUEIROZ, Suely R. R. de. “Sáo Paulo (1875-1975)”. In Separata da Revista de História. São Paulo, $n^{\circ}$ 108, 1976, pp. 447-449.

${ }^{22}$ CASALECCHI,José Ênio. OPartido Republicano Paulista. São Paulo, Brasiliense, 1987, pp. 42-43.

${ }^{23}$ BOEHRER, George C. A. Da monarquia à república: história do partido republicano do Brasil (1870-1900). Rio de Janeiro, Ministério da Educação e Cultura, s/d, pp. 110-111.

${ }^{24}$ DEBES, Célio S. Constituição, estrutura e atuação do Partido Republicano de São Paulo na propaganda (1872-1889). Dissertação de Mestrado, São Paulo, FFLCH-USP, 1975, pp. 70-75.

$122{ }^{25}$ Os outros dois ideólogos de maior destaque -Francisco Eugênio Pacheco e Silva eJoaquim Fernando de Barros -também publicaram livros separatistas, no entanto, estas obras não passaram de uma compilação dos artigos dos jornais. Por isso, esses textos foram apenas citados, tendo a análise sido feita a partir do que foi publicado nos periódicos.

${ }^{26}$ Ver capítulo 01, ADUCCI, Cássia C. op. cit.

${ }^{27}$ O livrofoi publicado em abril de 1887 com o título Propaganda Separatista. S. Paulo Independente.

${ }^{28}$ As discussóes sobre os cortes ou a ausência de verbas para aforça policial paulista esteve muito presente nas reclamações, principalmente de Nemo.

${ }^{29}$ A Província de São Paulo, 08/02/1887.

${ }^{30}$ ANDRADA, Martim Francisco R. de. Propaganda separatista. S. Paulo Independente. Sáo Paulo, s./e., 1887, p. 03.

${ }^{31}$ Idem, p. O4. Oautor fazia referência à sua primeira circular, na qual já constava uma destacada preocupação com os interesses da província e um certo orgulbo paulista. Em discurso pronunciado na assembléia em fevereiro de 1879, o autor também citou esta circular: "Quando dirigi minba circular ao corpo eleitoral, tive a franqueza de declarar que considerava mais glorioso o nome de paulista do que o de brazileiro; e o anno passado declarei neste recinto que sempre que se achasse em jogo, de um lado a Constituição do Imperio, $e$ de outro os interesses da província de S. Paulo, eu náo teria duvida em collocar estes em primeiro lugar" (Anais da Assembléia Legislativa Provincial de São Paulo, $1^{a}$ sessão, 12 de fevereiro de 1879, pp. 06-07).

${ }^{32}$ ANDRADA, Martim Francisco R. de. op. cit., p. 06. 
${ }^{33}$ Em estudo sobre as idéias republicanas, Maria Stela Bresciani aponta a existência, já em 1870, de afirmaçốes feitas por Campos Sales sobre descontentamentos que reapareceriam nos discursos separatistas anos depois. Destaca a autora: 'As características do cargo administrativo tinbam desdobramentos em todas as áreas onde otraballo individual se via tolbido pelos desmandose pelo descaso administrativos. Oque adiantava as províncias se empenbarem na exploração de sua riqueza se no fim a contribuição delas destinava-se aos gastos irrestritos da corte? De que servia a crescente fortuna particular fecundar a riqueza pública'se quando a província precisava de estradas de ferro, por exemplo, tinba de voltar-se para as companhias formadas com capitais particulares?Qual o sentidode todo o conjunto de esforços individuais se a riqueza particular eradrenada para manter um 'imenso funcionalismo assalariado e sem trabalbo, verdadeiro sangue-suga do orçamento, a pior das doenças sociais'? 'São os encantos da centralização, é a desgraça do Brasil', conchi um dos artigos republicanos'. BRESCIANI, Maria Stela. Liberalismo: ideologia e controle social. Tese de Doutorado, São Paulo, FFLCH-USP, 1976, p. 186.

${ }^{34}$ Diário Popular, $1^{\circ} / 04 / 1887$.

${ }^{35}$ FREITAS, Leopoldo de. Perfil biographico e politico de Martim Francisco. São Paulo, Typ. King, 1896, p. 10.

${ }^{36}$ Diário Popular, 24/03/1887.

${ }^{37}$ Diário Popular, 16/06/1887.

${ }^{38}$ O primeiro número de A Província de São Paulofoi publicado em 1875. Republicano, ojornal foi dirigido por Rangel Pestana e Américo de Campos até a saída deste e de José Maria Lisboa (administrador dojornal) para a fundação do Diário Popular. Alberto Sales substituiu Lisboa passando a atuar como redator e tornado-se co-proprietário do jornal. Sales permaneceu ligado ao jornal até 1886 quando foi substituído porJúlio Mesquita. FREITAS, Affonso Antônio de. A imprensa periódica de São Paulo desde os seus primórdios em 1823 até 1914. São Paulo, Typ. do Diário Oficial, 1915, p. 217.

${ }^{39}$ Ojornal Diário Popular começou a circular em 1884, sob a direçáo de Américo de Campos eJosé Maria Lisboa. Também republicano, ojornal é apontado por Affonso Antônio de Freitas como "o mais popular de todos os periódicos da capital, principalmente entre as classes menosfavorecidas”. Asjustificativas do autor sáo o preço e a facilidade de acessoàs colunas dojornal quando se tratava da desfesa de idéias "justas". FREITAS, Affonso Antônio de. op. cit., p. 290.

${ }^{40}$ FREITAS, Affonso Antônio de. op. cit., p. 316.

${ }^{41}$ Correio Paulistano, 20/09/1887. Este artigo recebeu críticas no Diário Popular de 29/09/1887. Na Gazeta de Campinas de 28/08/1887, Iskander foi identificado como o secretário do governo da província.

${ }^{42}$ A Província de São Paulo, 15/06/1887.

${ }^{43}$ A Província de São Paulo, 17/06/1887.

${ }^{44}$ Idem.

${ }^{45}$ A Província de São Paulo, 25/03/1887.

${ }^{46}$ ANDRADA, Martim Francisco R. de., Abolicionismo e separatismo, 1888, p. 10.

${ }^{47}$ SAES, Décio. op. cit., pp. 256-259.

${ }^{48}$ Este trecho, utilizado por Robert Conrad, foi, por sua vez, citado por Evanson que teria interpretado estas palavras "como constituindo 'um dos primeiros exemplos do moderno separatismo paulista'”. CONRAD, Robert. Os últimos 
anos da escravatura no Brasil (1850-1888). $2^{a}$ ed., Rio de Janeiro, Civilização Brasileira, 1978, p. 167.

${ }^{49}$ AZEVEDO, Célia Maria M. de. Onda negra, medo branco. Rio de Janeiro, Paze Terra, 1987, p. 122.

${ }^{50}$ Anais da Assembléia Legislativa Provincial de São Paulo, p. 268.

${ }^{51} \mathrm{O}$ medo de um desequilíbrio de forças entre as províncias do norte e do sul vinha desde 1875. Em 1878, como mostra Célia Maria M. de Azevedo, oparecer que acompanbava o projeto antitráfico lembrava "logo de início que a maior acumulação de escravos em uma ou duas províncias levaria a um fatal desequilíbrio nacional, visto que as outras estariam desimpedidas para só atender às necessidades reformistas 'de ordem moral e social' e por isso precipitariam 'a solução', ou seja, ofim da escravidão”. AZEVEDO, Célia Maria M. de. op. cit., p. 119.

${ }^{52}$ Anais da Assembléia Legislativa Provincial de São Paulo, p. 268.

${ }^{53}$ Citado por AZEVEDO, Célia Maria M. de. op. cit., pp. 119-120.

${ }^{54}$ Uma posição de Martim Francisco mais próxima ao abolicionismo pode ser apreendida ainda em artigo de 21 de julbo, no qual Nemo lamentou a derrota do marechal Deodoro da Fonseca em eleiçóes para uma cadeira no Senado. A candidatura de Deodoro estava associada ao abolicionismo conforme se percebe por informaçóes veiculadas pelojornal de Quintino Bocaiúva: "O general Deodoro declarou, então, que não se apresenta filiado a nenbum partido, abraçando sòmente as idéias abolicionistas". Citado por SODRÉ, Nelson Werneck. História da imprensa no Brasil. Rio de Janeiro, Civilização Brasileira, 1966, p. 273. Ainda segundo o texto de Nelson Werneck Sodré, o marechal 124 teria recebido o apoio de Patrocínio.

${ }^{55}$ HADDAD, Jamil A. op. cit., p. 175.

${ }^{56}$ MARTINS, Wilson. op. cit., p. 247.

${ }^{57}$ HOLANDA, Sérgio Buarque de. op. cit., p. 06. 